\title{
Modes of Qiraat in Sunan Al-Tirmidhiyy: Analysis of Selected Hadis
}

\section{Azizul Bin Hassan}

To Link this Article: http://dx.doi.org/10.6007/IJARBSS/v10-i12/8345

DOI:10.6007/IJARBSS/v10-i12/8345

Received: 21 October 2020, Revised: 18 November 2020, Accepted: 30 November 2020

Published Online: 26 December 2020

In-Text Citation: (Hassan, 2020)

To Cite this Article: Hassan, A. Bin. (2020). Modes of Qiraat in Sunan Al-Tirmidhiyy: Analysis of Selected Hadis. International Journal of Academic Research in Business and Social Sciences, 10(12), 477-486.

\section{Copyright: ( 2020 The Author(s)}

Published by Human Resource Management Academic Research Society (www.hrmars.com)

This article is published under the Creative Commons Attribution (CC BY 4.0) license. Anyone may reproduce, distribute, translate and create derivative works of this article (for both commercial and non-commercial purposes), subject to full attribution to the original publication and authors. The full terms of this license may be seen

at: http://creativecommons.org/licences/by/4.0/legalcode

Vol. 10, No. 12, 2020, Pg. 477 - 486

Full Terms \& Conditions of access and use can be found at http://hrmars.com/index.php/pages/detail/publication-ethics 


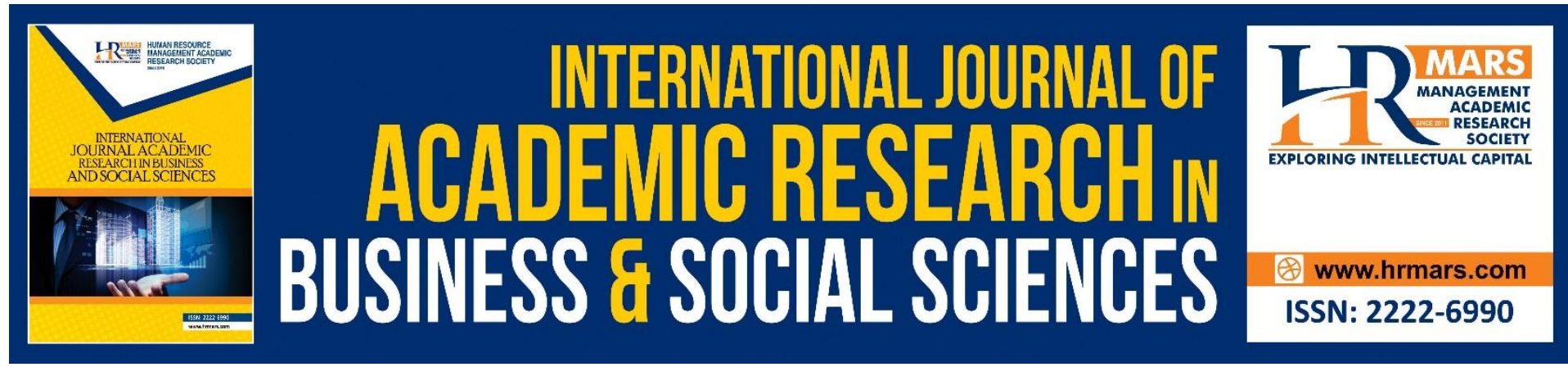

\title{
Modes of Qiraat in Sunan Al-Tirmidhiyy: Analysis of Selected Hadis
}

\author{
Azizul Bin Hassan \\ Faculty of Islamic Contemporary Studies Universiti Sultan Zainal Abidin \\ Email: azizulhassan@unisza.edu.my
}

\begin{abstract}
Sunan al-Tirmidhiyy is one of the six renowned books of hadis known as al-Kutub al-Sittah, which are Sahih al-Bukhariyy, Sahih Muslim, Sunan al-Tirmidhiyy, Sunan Abu Daud, Sunan alNasa'iyy and Sunan Ibn Majah. Sunan al-Tirmidhiyy is a work of Imam al-Tirmidhiyy containing various types of knowledge such as knowledge of Fiqh (Islamic Jurisprudence), Akidah (Faith), Sirah (Islamic History), Adab (Moral), Qiraat (Modes of Quranic Recitation), Tafsir (Quranic Exegesis) and others. Among the advantages of Sunan al-Tirmidhiyy is that there are selected hadis put under specific title related to Qiraat. Therefore, this article is intending to analyse modes of Qiraat contained in those selected Qiraat. Results of the analysis performed showed that there are sixteen pronouncements regarding with the modes of Qiraat either of Qiraat Mutawatirah mode or Qiraat Shadhdhah mode and the total of related hadis is of fifteen hadis. Besides that, it was also found that there are nine surahs containing modes of Qiraat, which are surah al-Fatihah, surah Hud, surah al-Kahf, surah al-Rum, surah al-Qamar, surah alWaqiaah, surah al-Layl, surah al-Dhariyat and surah al-Hajj.
\end{abstract}

Keywords: Sunan al-Tirmidhiyy, Qiraat, Selected Hadis

\section{Introduction}

The full name or the real nama of the book Sunan al-Tirmidhiyy is al-Jami' al-Mukhtasar An Rasulillah Fi Marifah al-Sahih Wa al-Ma'lul Wa Ma Alayh al-Amal. This book is also known as Jami' al-Tirmidhiyy (Al-Tirmidhiyy, 2004). Sunan al-Tirmidhiyy is a book of hadis serving as reference in field of hadis after the book Sahih al-Bukhariyy and Sahih Muslim, in fact it is even regarded as more useful as everyone is able to gain benefits from the Sunan alTirmidhiyy. This book compiles hadis related to various knowledge especially Figh knowledge in which its contents are practised by Fuqaha'. Imam al-Tirmidhiyy mentioned the status for hadis contained in his book either of hadis hasan (Al-Suyutiyy, 1989: 156), hadis hasan sahih, hadis gharib or hadis hasan gharib, including hadis describing the modes of Qiraat. One matter that should be paid attention is that the modes of Qiraat included in those hadis are not necessarily included in category of Qiraat Mutawatirah. Hence, an examination to modes of Qiraat mentioned in those hadis should be given due attention to uphold the studies of alHadis and al-Qiraat. 


\section{Biodata of Imam Al-Tirmidhiyy}

Brief biodata of Imam al-Tirmidhiyy is mentioned as follows:

\section{Name, Lineage, Date of Birth \& Decease}

His name was Muhammad Bin Isa Bin Sawrah Bin Musa Bin al-Dahhaq (al-Zahabiyy, 2004: 1257). Abu Isa was his nickname or kunyah of Imam al-Tirmidhiyy. He was born in Tirmidh in the month of Zulhijjah year 209 Hijri and deceased in Tirmidh on Monday night in the month of Rejab year 279 Hijri.

\section{His Teachers \& Students}

Imam al-Tirmidhiyy had many teachers and students. Among his teachers were al-Bukhariyy, Muslim, Qutaybah Bin Said, Ishaq Bin Rahawiyah and Muhammad Bin Amr al-Sawaq alBalkhiyy, while the students who sought knowledge from him were Ahmad Bin Ismail Bin Amir al-Samarqandiyy and Ahmad Bin Abdillah Bin Dawud al-Marwaziyy.

\section{Scholarship of Imam Al-Tirmidhiyy}

Imam al-Tirmidhiyy produced writings of books which are very beneficial to the readers especially regarding hadis and Prophet Muhammad S.A.W. Among his works of writing are Kitab al-Jami' al-Sahih, Kitab al-Shama'il al-Muhammadiyyah, Kitab Tasmiyah Ashab Rasulilah, Kitab al-Ilal and Kitab al-Tawarikh.

\section{Modes of Qiraat in Sunan Al-Tirmidhiyy}

Imam al-Tirmidhiyy had compiled fifteen hadis containing modes of Qiraat in his sunan. A total of ten surahs are involved in those modes of recitation. The modes of Qiraat mentioned encompass Qiraat Mutawatirah mode and Qiraat Shadhdhah mode. Generally, he included more Qiraat Mutawatirah modes than Qiraat Shadhdhah modes in the book. Discussion on the modes of Qiraat was explained based on the following hadis:

\section{First Hadis}

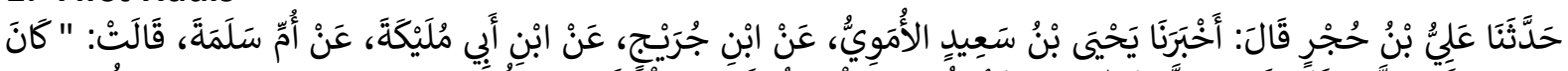

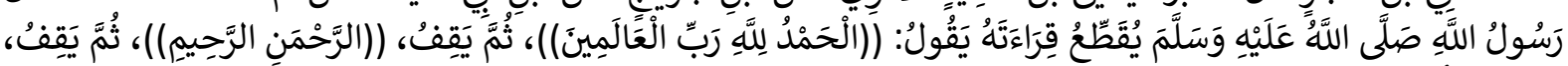

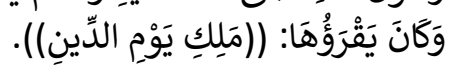

\section{Second Hadis}

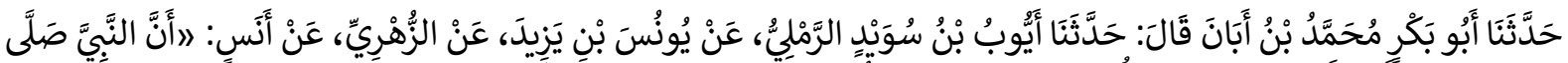

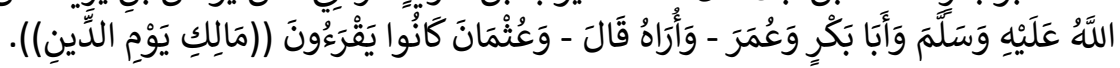

Based on the first and second hadis, the modes of Qiraat stared include the pronuncements

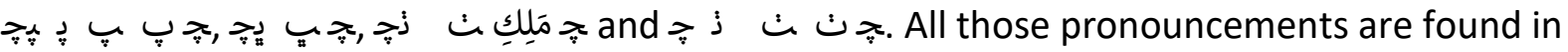
surah al-FÉtilah. The first pronouncement is $\vartheta_{\forall}$ pronouncement is حالحَمْدُ لِلَّهِ grammar knowledge, the word جالحَمْدُح *baris depan. This qiraat is a Qiraat Mutawatirah because the pronouncement is agreed of its recitation without khilaf (Jamal al-Din, 2006: 1). The second Qiraat is that the letter Dal and the letter Lam, which is and Sufyan Bin Uyaynah (Abu-Hayyan, 1993: 131). The third Qiraat is that the letter Dal and letter Lam is recited with *baris bawah, which is This Qiraat was narrated by al- 
Hasan al-Basriyy (Kharuf, 2006: 1; Mughal, 2019) and Zayd Bin Aliyy (Abu-Hayyan, 1993: 131) which is ruled as a Qiraat Shadhdhah. The concept applied for this type of recitation is by assigning the diacritic of the first letter based on the second letter (لأجل التجانس). It refers to lughah Tamim and lughah of some of Ghatafan.

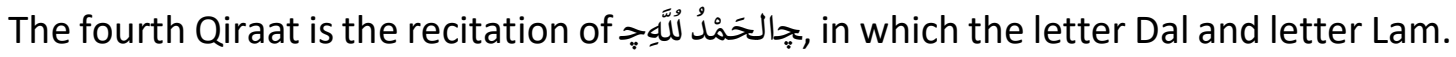
The letter Lam is pronounced with which is due to the diacritic of the letter Dal preceding it. This recitation concept refers to lughah of some of Qays that assigns diacritic of the second letter based on the first letter (Ibn-Adil, 1998: 173). This Qiraat was narrated by Ibn Abu Ublah. Besides Ibn Abi Ublah, the letter Lam in the word $*_{*}$ is pronounced with *baris bawah (alHudhaliyy, 2007: 478). Those elaborations are the modes of Qiraat in pronouncement

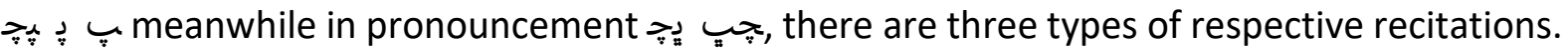
The first mode of Qiraat is that the letter Nun and letter Mim upon basis that they are sifat or badal (Ibn-Adil, 1998: 184). This Qiraat is a Qiraat Mutawatirah. The second Qiraat is that the

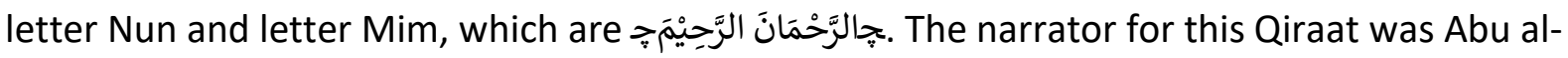
Aliyah, Ibn al-Samayfa, Isa Bin Umar (Abu-Hayyan, 1993: 132). The third Qiraat is that the letter Nun and letter Mim, which is Uqayliyy, al-Rabi' Bin Khaytham and Abu Imran al-Juniyy (Abu-Hayyan, 1993: 132).

Besides the modes of Qiraat in pronouncement various modes of Qiraat in pronouncement جنث after letter Mim and the letter Kaf, which is جنتج this type of recitation were Asim, al-Kisa'iyy (Muhammad Salim Muhaysin 1997: 33) and Ya'qub (ShihabudDin, 2005: 56, Ibn-al-Jazariyy, 2004: 82, Muhaysin, 2002: 41, Abd al-Fattah, 2005: 63). This Qiraat is Qiraat Mutawatirah and it was also narrated by al-Hasan al-Basriyy (Kharuf, 2006:1). The second Qiraat for the word $ح$ is no letter Alif after letter Mim and letter Kaf, which is جָمَلِكِ Qurra' of the ten Qiraat who narrated those both recitations, which

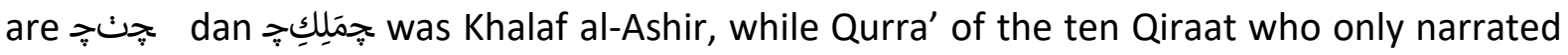

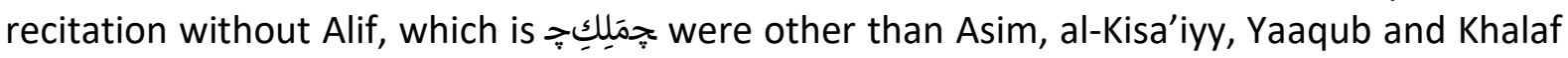
al-Ashir (Muhammad Fahd Kharuf 2006: 1). This Qiraat is ruled as a Qiraat Mutawatirah.

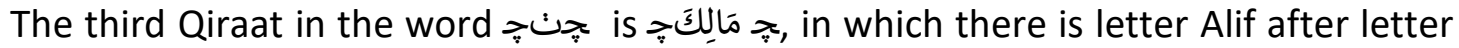
MÊm and letter Kaf. This Qiraat is a Qiraat Shadhdhah which was narrated by al-Muttawwiyy (Kharuf, 2006. 1) from al-Amash and Ibn al-Samayfa and also Abu Abd al-Malik (Ibn Adil 1998: 186). From aspect of syntactic knowledge, the letter Kaf as it is an object, which is maf'ul bih for the word 'I praise' or as a munada, which is 'someone who is called'. The fourth Qiraat is Qiraat narrated by Atiyyah Bin Qays (Ibn-Adil, 1998: 186). The Qiraat is in which there is no letter Alif after letter Mim and letter Kaf. This Qiraat is Qiraat Shadhdhah. The fifth Qiraat

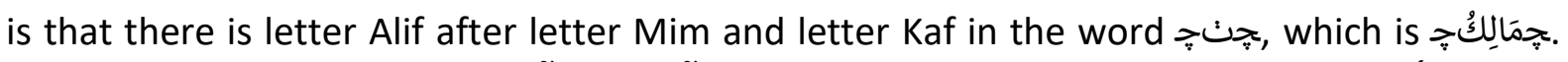
The narrator for this Qiraat was ÑAun al-ÑUqayliyy. This Qiraat is ruled as a Qiraat ShÉdhdhah. The sixth Qiraat is the Qiraat related to Abu Haywah Shurayh Bin Yazid. The Qiraat refers to the Qiraat in which there is no letter Alif after letter Mim and the letter Kaf in the word جָن

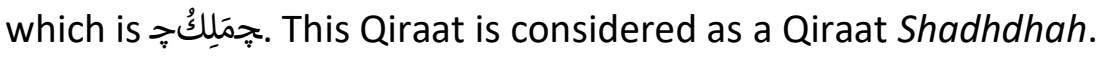

The seventh Qiraat is when there is no letter Alif after letter Mim and the letter Lam

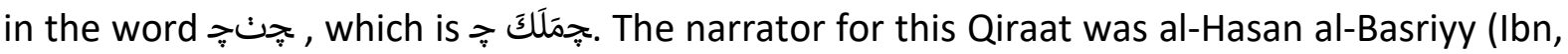
1998: 187). The word refers to a past tense. This Qiraat is a Qiraat Shadhdhah. The eighth 
Qiraat is imalah of the letter Mim and letter Alif in the word Yahya Bin Ya'mur.

\section{Third Hadis}

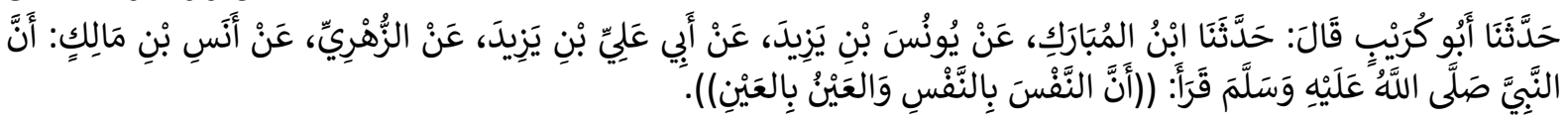

The third hadis states the various types of Qiraat mode occurring in five words, which are $\approx$

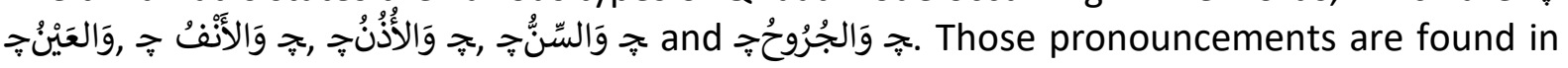
surah al-Ma'idah. It refers to the last letter in each of those words to be recited with *baris depan. This Qiraat was narrated by al-Kisa'iyy (al-Masarawiyy, 2009: 115). The second Qiraat for these pronouncements is that the last letter in each of those words is pronounced with

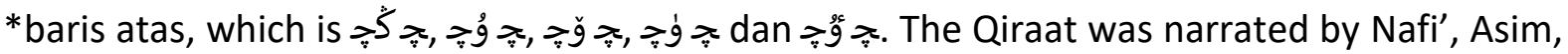
Hamzah, Ya'qub and Khalaf. One matter that should be concerned of is the mode of Qiraat that occurs in the word $ح$. was narrated by Nafi'. Besides Nafi', it was narrated with the letter Zal (Jamal al-Din, 2006: 115).

Besides that, there are also modes of Qiraat read with *baris atas at the end of each

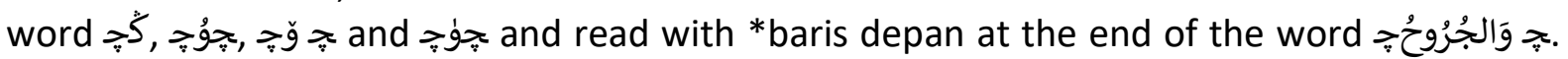
This Qiraat was narrated by Ibn Kathir, Abu Amr, Ibn Amir and Abu Jaafar. This Qiraat is a Qiraat Mutawatirah and was also narrated by Ibn Muhaysin, al-Yazidiyy and al-Shanabuziyy (Kharuf, 2006: 115). The word جالجُرُوحُح is recited with *baris depan as it refers to a subject,

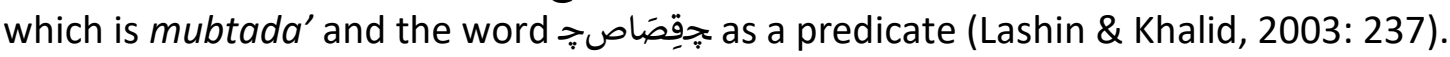

\section{Fourth Hadis}

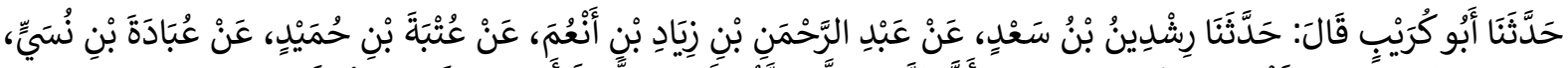

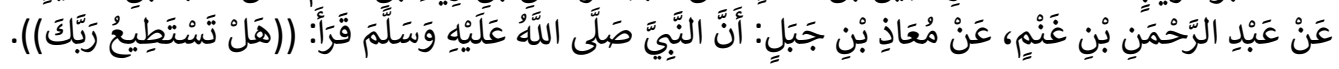

In this fourth hadis, there is a mode of Qiraat which is read with letter Ta', which is

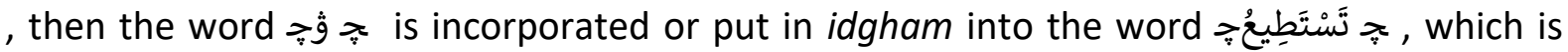

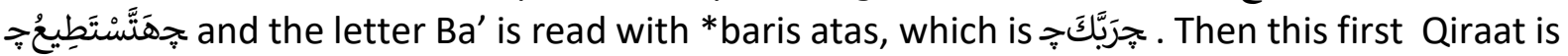

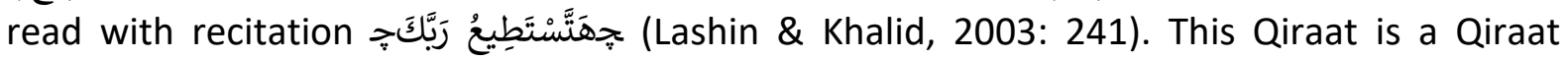
Mutawatirah narrated by al-Kisa'iyy (Jamal al-Din, 2006: 126). The second Qiraat for this

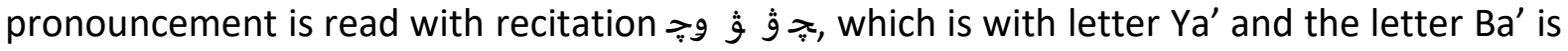
read with *baris depan without involving any idghÉm. This Qiraat is the one narrated by others besides al-Kisa'iyy (Kharuf, 2006: 126) and it also refers to a Qiraat Mutawatirah. The Qiraat is found in surah al-Ma'dah.

Fifth Hadis

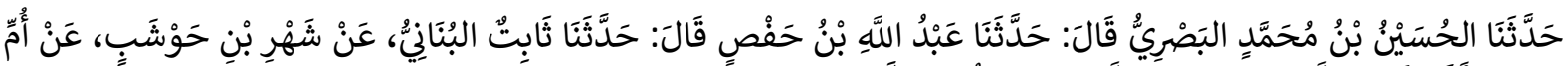

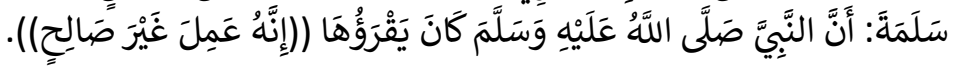

\section{Sixth Hadis}

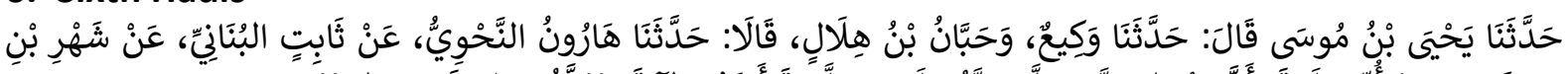

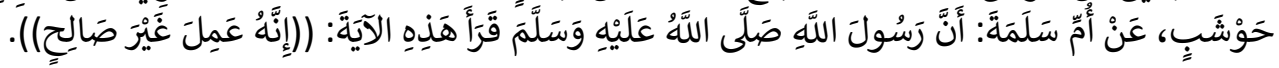


The mode of Qiraat found in the fifth and sixth hadis is that the letter Mim, Lam atas without tanwin and Ra', which is جعَمِلَ غَيَّرَ The pronouncement is found in surah Hud. This Qiraat was narrated by al-Kisa'iyy and Ya'qub (Kharuf, 2006: 227). This Qiraat refers to a Qiraat Mutawatirah. Besides al-Kisa'iyy and Ya'qub, those pronouncements are read with Mim , Lam

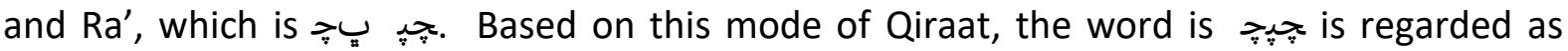
predicate of inna and the word $\vec{z}_{z}$ is regarded as sifat. (Lashin \& Khalid, 2003: 287). This Qiraat is also a Qiraat Mutawatirah. Besides that, al-Azraq narrated the recitation of Ra' in the word ${ }_{i}$ with pharyngealised and non-pharyngealised recitation, meanwhile Abu Ja'far put $i k h f a^{\prime}$ at tanwin, which is *baris dua di depan in the pronouncement Din, 2006: 227).

\section{Seventh Hadis}

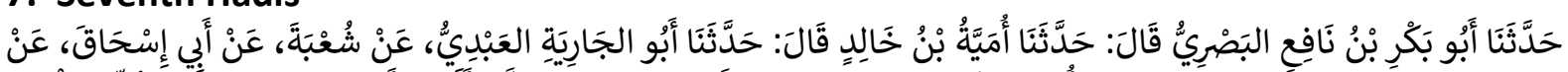

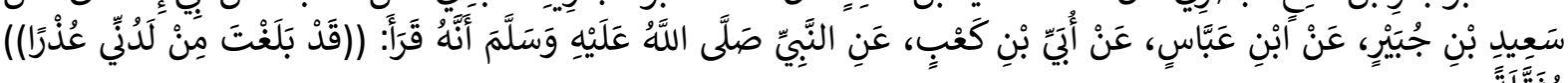

The pronouncement stated in this seventh hadis is found in surah al-Kahf. There are many different recitations narrated for the word Imam Nafi' and Abu Ja'far narrated the letter Dal with *baris depan and no tashdid for letter Nun, which is جلَّنُنِ letter Dal with consonant diacritic and put ishmam at letter Dal or put ikhtilas on *baris depan

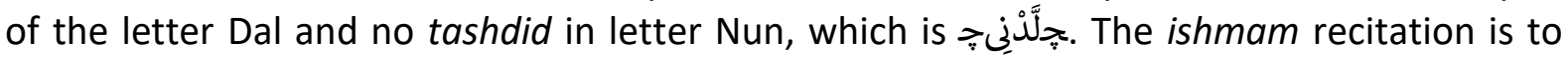
indicate that the original diacritic of letter Dal which is *baris depan and it is a Qiraat Mutawatirah. Besides Nafi', Abu Ja'far and Shu'bah, the word can be read with the letter Dal and there is tashdid in the letter Nun, which is $\underset{*}{*}$ (Jamal al-Din, 2006: 302 \& Kharuf, 2006: 302). This Qiraat is regarded as a Qiraat Mutawatirah.

\section{Eighth Hadis}

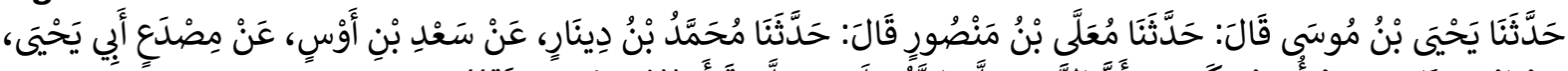

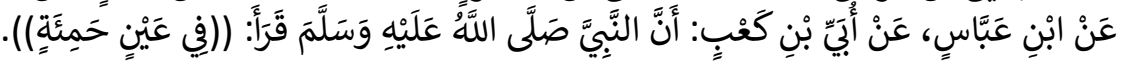

In this eighth hadis, there is a word from surah al-Kahf having different modes of Qiraat. The first Qiraat is no letter Alif after the letter Ha' and there is letter Hamzah after the letter Mim, which is $ح$. This Qiraat is accounted as a Qiraat Mutawatirah which was narrated by Nafi', Ibn Kathir, Abu Amr, Hafs and Ya'qub. This mode of Qiraat was also narrated by al-Yazidiyy. Those other than them narrated the word with recitation having letter Alif after the letter $\mathrm{Ha}^{\prime}$ and there is letter Ya' after the letter Mim, which is (Jamal al-Din, 2006: 303 \& Kharuf, 2006: 303).

\section{Ninth Hadis}

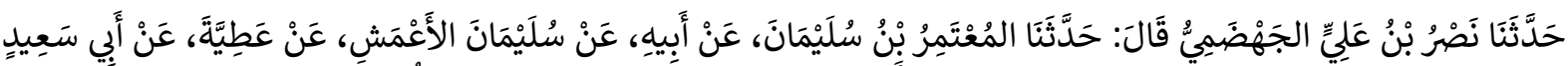

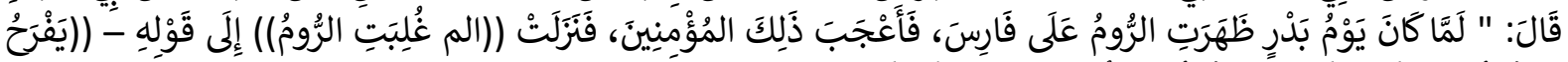

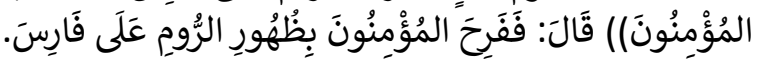

There are various Qiraat recitations in this hadis. The first Qiraat is the recitation of saktah at the letter Alif, Lam and Mim. This saktah recitation was narrated by Abu Ja'far. Besides him, the pronouncement is read without saktah, which is $\geqslant \rightarrow$. Those both types of recitation are Qiraat Mutawatirah (Jamal al-Din, 2006: 404 \& Kharuf, 2006: 404). The second Qiraat is 
imalah recitation during waqaf at the word جَ أَدْنى:. This Qiraat was narrated by Hamzah, alKisa'iyy and Khalaf al-Ashir. This Qiraat is a Qiraat Mutawatirah and was narrated also by alA'mash. Al-Azraq narrated the word with fath recitation, which is letter Nun and taqlil. This recitation is a Qiraat Mutawatirah. Other than them, the word is only read with fath, which is $\underset{\sharp}{z}$. This Qiraat is also regarded as a Qiraat Mutawatirah (Jamal al-Din, 2006: 404). Those stated pronouncements are found in surah al-Rum.

\section{Tenth Hadis}

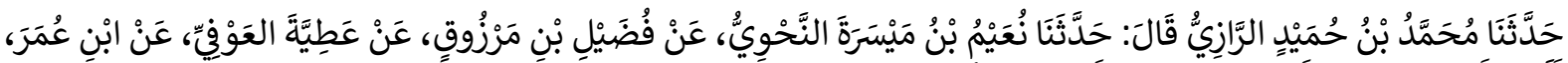

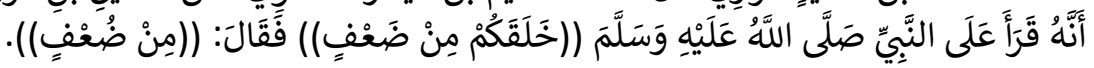

There are modes of Qiraat in the three words contained in the tenth hadis. The pronouncement which is related to the Qiraat is found in surah al-Rum. Those both types of Qiraat involve diacritic at the letter Dad. The first Qiraat is that the letter Dhad only, which are

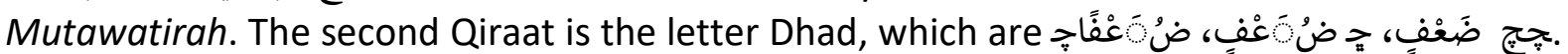
This Qiraat is a Qiraat Mutawatirah narrated by Hafs. Besides them, the letter Dad is read

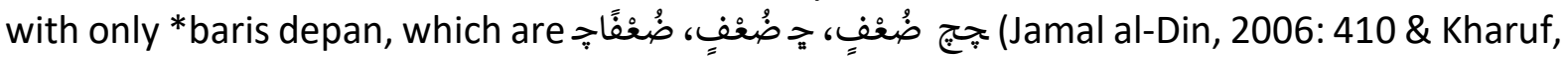
2006: 410).

\section{Eleventh Hadis}

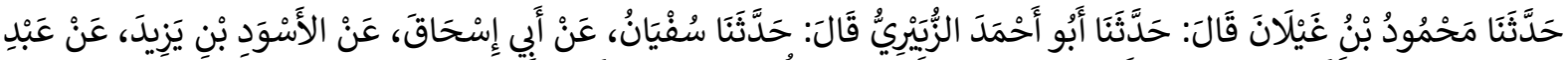

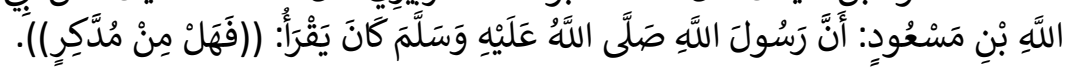

All the Ten Qurra' agreed that there is no khilaf or different recitation for the pronouncement

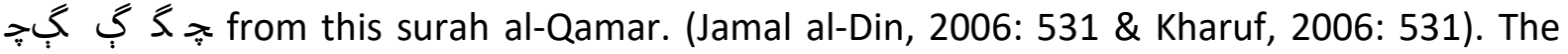
recitation refers to a Qiraat Mutawatirah.

\section{Twelfth Hadis}

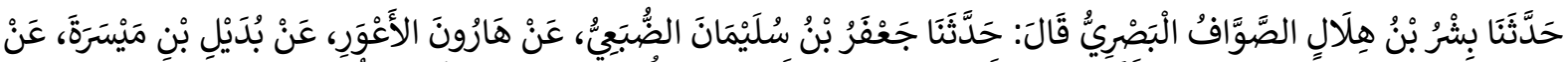

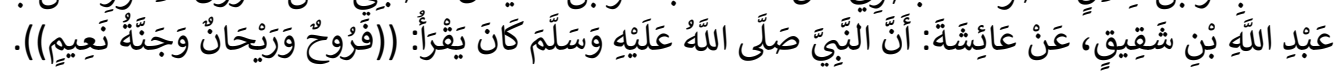

There are two types of Qiraat in the twelfth hadis. It occurs in the word

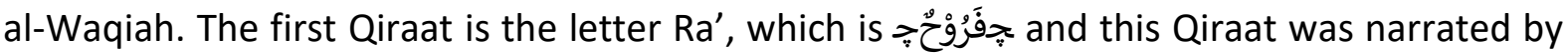
Ruways. This Qiraat is regarded as a Qiraat Mutawatirah and was also narrated by al-Hasan. Besides Ruways, the word is also read with Ra' which is also a Qiraat Mutawatirah, which is جצ (al-Din, 2006: 537, al-Ma'sarawiyy, 2006: 118, al-Ma'sarawiyy, 2009: 537; Kharuf, 2006: 537).

\section{Thirteenth Hadis}

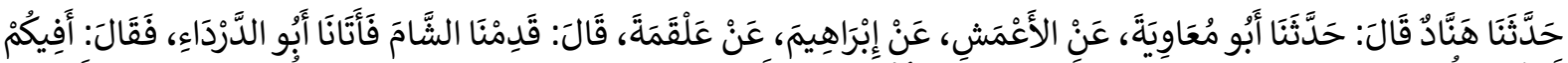

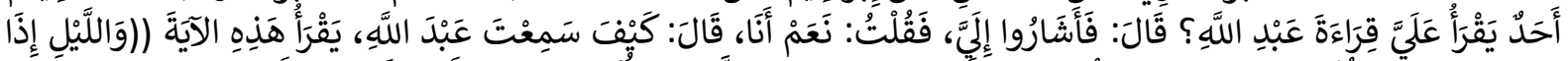

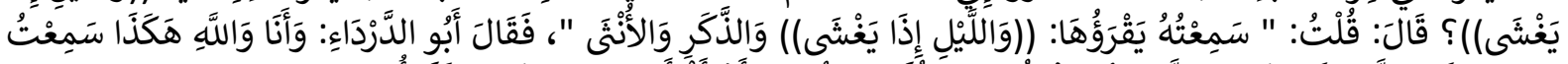

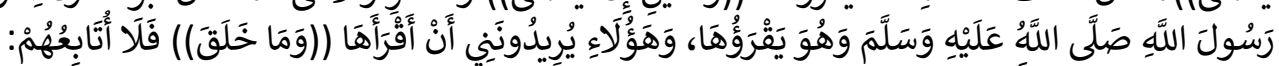
The pronouncement in the thirteenth hadis, which is the pronouncement $\vec{b} \quad$ is not a Qiraat Mutawatirah, in fact it is not considered as a Quranic verse (al- 
Ma'sarawiyy, 2006: 130). While for Qiraat Mutawatirah in this surah al-Layl, among them is the one involving the word and Khalaf. Al-Azraq and Abu Amr narrated the pronouncements with recitation of imalah and taqlil (Jamal al-Din, 2006: 595). It is also a Qiraat Mutawatirah. Besides them, those pronouncements are read with fath.

\section{Fourteenth Hadis}

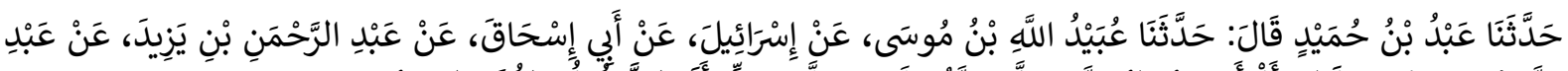

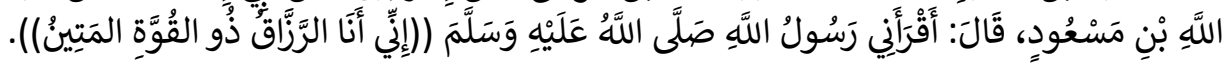

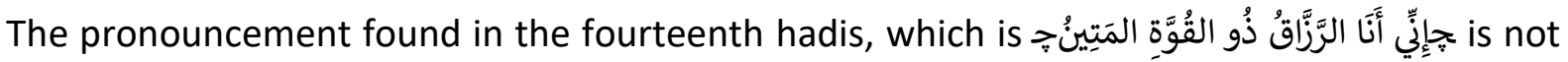
regarded as a Quranic verse (al-Ma'sarawiyy, 2006: 112). While Qiraat Mutawatirah contained in the verse is of two recitation modes, which is izhar recitation to the letter $\mathrm{Ha}$ ' in the word

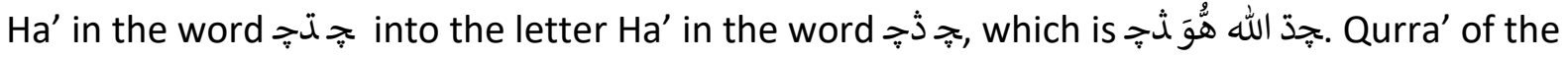
Ten Qiraat who narrated those both modes of recitation were Abu Amr and Ya'cub. Those other than them only narrated izhar recitation alone (Jamal al-Din, 2006: 523). Those modes of recitation are Qiraat Mutawatirah. These stated pronouncements are found in surah al-

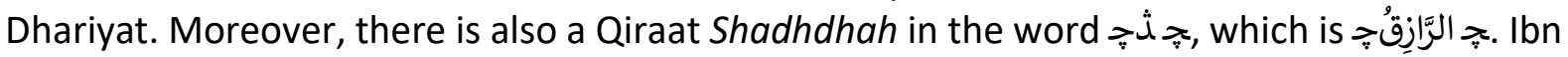

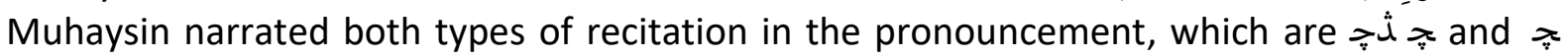

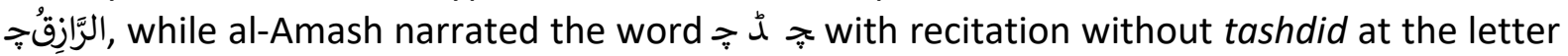

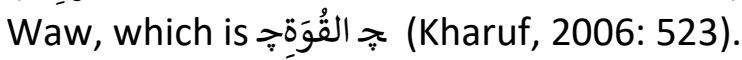

\section{Fifteenth Hadis}

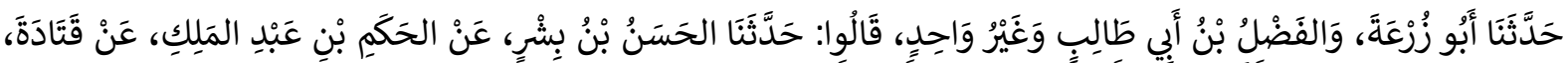

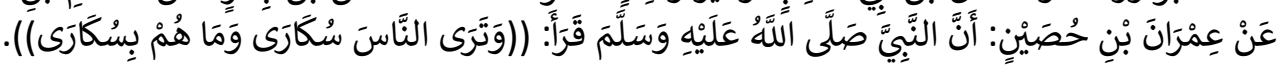

There are two words in the fifteenth hadis having two types of recitation. Those recitations are found in surah al-Hajj. The first mode of Qiraat is the letter Sin with *baris atas and letter Kaf of non-voweled diacritic (al-Ma'sarawiyy, 2006: 95) and imalah of letter Ra' and Alif, which

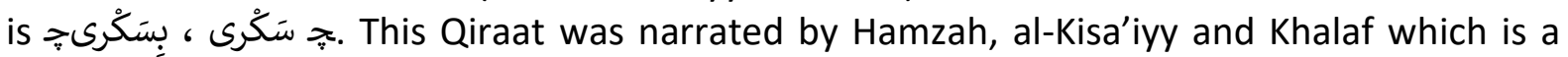
Qiraat Mutawatirah (al-Din, 2006: 332). It was also narrated by al-Amash (Mulammad Fahd Kharuf 2006: 332). The second Qiraat is that the letter Sin the letter Kaf read with *baris atas there is letter Alif after letter Kaf (al-Ma'sarawiyy, 2006: 95) together with taqlil recitation. This Qiraat is a Qiraat Mutawatirah narrated by al-Azraq. The third Qiraat is the letter Sin, letter Kaf and there is letter Alif after letter Kaf together with imalah recitation only. It was narrated by Abu Amr and is also a Qiraat Mutawatirah. The same mode of Qiraat was also narrated by al-Yazidiyy. The fourth Qiraat is the letter Sin, letter Kaf and there is letter Alif after letter Kaf together with imalah and fath recitations, which is a Qiraat Mutawatirah narrated by Ibn Dhakwan (Al-Din, 2006: 332 \& Kharuf, 2006: 332).

\section{Conclusion}

Based on the analysis performed to the modes of Qiraat in sunan al-Tirmidhiyy, it can be concluded that the hadis compiled by Imam al-Tirmidhiyy do not include all modes of Qiraat and are not comprehensive for all surahs of al-Quran even though they were put under a specific chapter regarding Qiraat. Besides that, modes of Qiraat narrated through those hadis encompass Qiraat Mutawatirah and Qiraat Shadhdhah. Examination to those modes of Qiraat 
in a certain hadis should be concerned of. This is for the sake of proving that not all modes of Qiraat contained in hadis book can be accepted and practised and considered sahih without referring in advance to Qurra' and their writings. Looking at the basis of al-Quran and al-Qiraat studies which is based on talaqqi and mushafahah concept, then the priority of taking the knowledge is through teachers who receive recognition, support, reference and permission from their teachers known as sanad and ijazah of al-Quran.

\section{References}

Al-Hayyan, A. (1993). Tafsir al-Bahr al-Muhit. Bayrut: Dar al-Kutub al-Ilmiyyah

Al-Hudhaliyy, A. A. Y. (2007). Al-Kamil Fi al-Qiraat Wa al-Arbain al-Za'idah Alayha. Al-Qahirah: Mu'assasah Sama Li al-Tawzi Wa al-Nashr

Al-Ma'sarawiyy, I. A. (2006). al-Qira'at al-Waridah Fi al-Sunnah. Qahirah: Dar al-Salam

Al-Ma'sarawiyy, I.A. (2009). Al-Kamil al-Mufassal Fi al-Qira'at al-Arba'ah Ashar. Qahirah: Dar al-Imam al-Shatibiyy

Al-Suyutiyy, B. A. J. (1989). Tadrlb al-Rawi Fi Sharh Taqrib al-Nawawiyy. Bayrut: Dar al-Kutub al-Ilmiyyah

Al-Tirmidhiyy, I. M. (2004). Sunan al-Tirmidhiyy. Al-Qahirah: Dar Ibn al-Haytham

Al-Dhahabiyy, U. A. (2004). Sayr A'lam al-Nubala'. Lubnan: Bayt al-Afkar al-Dawliyyah

Al-Qadi, A. A. (2005). Al-BudUr al-Zahirah Fi al-Qiraat al-Ashrah al-Mutawatirah. Al-Qahirah:

Dar al-Salam

Ibn-Jazariyy. (2004). Tahbir al-Taysir Fi Qiraat al-A'immah al-Ashrah. Tanta: Dar al-Sahabah Lil Turath

Ibn-Adil. (1998). Al-Lubab Fi Ulum al-Kitab. Bayrut: Dar al-Kutub al-Ilmiyyah

Sharaf, M. J. (2006). Mushaf Dar al-Sahabah Fi al-Qira'at al-Ashr al-Mutawatirah Min Tariq Tayyibah al-Nashr. Tanta: Dar al-Sahabah Lil Turath

Kharuf, M.F. (2006). Al-Muyassar Fi al-Qiraatt al-Arba Ashrah. Bayrut: Dar Ibn Kathir

Muhaysin, M. S. (1997). Al-Irshadat al-Jaliyyah Fi al-Qiraat al-Sab' Min Tariq al-Shatibiyyah. Bayrut: Dar al-Jayl

Muhaysin, M. S. (2002). Al-Muhadhdhab Fi al-Qiraat al-Ashr Wa Tawjihiha Min Tariq Tayyibah al-Nashr. Al-Qahirah: al-Maktabah al-Azhariyyah Lil Turath

Al-Farah, A., \& al-Hafiz, K. M. (2003). Taqrib al-Ma'ani Fi Sharh Hirz al-Amani Fi al-Qira'at alSab. Al-Mamlakah al-Arabiyyah al-Su'udiyyah: Maktabah Dar al-Zaman.

Syihabuddi, M. A. B. (2005). Sharh Tayyibah al-Nashr Fi al-Qiraatt al-Ashr. Tanta: Dar alSahabah Lil Turath

Mokhtar, W. K. A. W., Khairuldin, W. M. K. F. W., Ibrahim, A., \& Embong, A. H. (2018). Al'Aqīdat Al-Șahīḥat as the Essential Element of Worldview of Development Integrity and Accountability. International Journal Of Academic Research In Business And Social Sciences, 8(11), 328-337.

Ridzuan, F. N. B., Mokhtar, W. K. A. W., Afifah, A., Amiruddin, R. E., \& Jamaludin, A. S. (2019). The Characteristic And Issues In Liberal Islam In Malaysia. International Journal Of Academic Research In Business And Social Sciences, 9(11).

Hamid, N. C., \& Mokhtar, W. K. A. W. (2019). The Comprehensive Aspect In Islam From Quran And Hadith Perspective. International Journal Of Academic Research In Business And Social Sciences, 9(11).

Hamid, N. C., \& Mokhtar, W. K. A. W. (2019). The Comprehensive Aspect in Islam from Quran and Hadith Perspective. International Journal Of Academic Research In Business And Social Sciences, 9(11). 
Mughal, H. A. (2019). Support at Work and its Relationship with Employee Performance:

Critical Insights for Early Scholars. Annals of Contemporary Developments in Management \& HR (ACDMHR), 1(3), 16-21.

Nafi, N. M., Mokhtar, W. K. A. W., \& Mustaffami, M. (2019). The Holy Quran Memorization In Globalization Era. International Journal Of Academic Research In Business And Social Sciences, 9(11). 